\title{
THE NEMATICIDAL EFFECT OF SOME BACTERIAL BIOFERTILIZERS ON MELOIDOGYNE INCOGNITA IN SANDY SOIL
}

\author{
M.E. El-Hadad ${ }^{1}$, M.I. Mustafa ${ }^{1}$, Sh.M. Selim ${ }^{1}$, T.S. El-Tayeb ${ }^{1}$, A.E.A. Mahgoob ${ }^{2}$, Norhan H. Abdel Aziz ${ }^{3}$ \\ ${ }^{1}$ Department of Agricultural Microbiology, Faculty of Agriculture, Ain Shams University, Shoubra El-Kheima, 11241, Cairo, \\ Egypt; ${ }^{2}$ Department of Plant Protection, Faculty of Agriculture, Ain Shams University, Shoubra El-Kheima, 11241, Cairo, Egypt; \\ ${ }^{3}$ Central Laboratory for Agricultural Climate, Agricultural Research Center, Ministry of Agriculture, 12411, Giza, Egypt.
}

Submitted: March 17, 2010; Returned to authors for corrections: April 06, 2010; Approved: June 21, 2010.

\begin{abstract}
In a greenhouse experiment, the nematicidal effect of some bacterial biofertilizers including the nitrogen fixing bacteria (NFB) Paenibacillus polymyxa (four strains), the phosphate solubilizing bacteria (PSB) Bacillus megaterium (three strains) and the potassium solubilizing bacteria (KSB) B. circulans (three strains) were evaluated individually on tomato plants infested with the root-knot nematode Meloidogyne incognita in potted sandy soil. Comparing with the uninoculated nematode-infested control, the inoculation with $P$. polymyxa NFB7, B. megaterium PSB2 and B. circulans KSB2, increased the counts of total bacteria and total bacterial spores in plants potted soil from 1.2 to 2.6 folds estimated 60 days postinoculation. Consequently, the inoculation with $P$. polymyxa NFB7 increased significantly the shoot length (cm), number of leaves / plant, shoot dry weight (g) / plant and root dry weight (g)/ plant by $32.6 \%, 30.8$ $\%, 70.3 \%$ and $14.2 \%$, respectively. Generally, the majority treatments significantly reduced the nematode multiplication which was more obvious after 60 days of inoculation. Among the applied strains, $P$. polymyxa NFB7, B. megaterium PSB2 and B. circulans KSB2 inoculations resulted in the highest reduction in nematode population comparing with the uninoculated nematode-infested control. They recorded the highest reduction in numbers of hatched juveniles/root by $95.8 \%$, females/root by $63.75 \%$ and juveniles $/ 1 \mathrm{~kg}$ soil by $57.8 \%$. These results indicated that these bacterial biofertilizers are promising double purpose microorganisms for mobilizing of soil nutrients (nitrogen, phosphate and potassium) and for the biological control of M. incognita.
\end{abstract}

Key words: Paenibacillus polymyxa, Bacillus megaterium, B. circulans, biofertilizers, biocontrol, rootknot nematodes, Meloidogyne incognita.

\section{INTRODUCTION}

Root-knot nematodes Meloidogyne spp., are obligate endoparasites of great economic importance, being among the major limiting factors in the production of field and plantation crops, predominantly in the tropics but also in Europe and
North America (17).

A number of methods for the management of root-knot nematode such as chemical control, organic amendments, and biological control have been tried with different levels of successes for the protection of tomato plants $(22,24)$. Chemical management is effective, but expensive and may lead

*Corresponding Author. Mailing address: Department of Agricultural Microbiology, Faculty of Agriculture, Ain Shams University, Shoubra El-Kheima, 11241, Cairo, Egypt.; E-mail: tarekeltayeb@yahoo.com 
to soil pollution problems (32). Over the last decades, researchers all over the world are engaged in standardizing the nematode management strategies by following non-chemical and ecofriendly approaches $(3,21,31)$. A great diversity of rhizospheric microorganisms has been described, characterized, and tested for activity as biocontrol agents against soil nematodes. These microorganisms possess some mechanisms to promote plant growth and control pathogens. Explanation among ecological interactions that occur between nematodes and bacteria, amensalism and parasitism happens in soil largely as the result of the stepwise bacterial degradation of plant and animal residues. The widely recognized mechanisms of biocontrol mediated by plant growth promoting bacteria (PGPB) are competition for an ecological niche or a substrate, production of inhibitory substances, and induction of systemic resistance in host plants to a broad spectrum of pathogens and/or abiotic stresses (7, 13). Paenibacillus polymyxa, B. megaterium and B. circulans are common soil bacterial biofertilizers belonging to plant growth promoting bacteria (PGPB). Activities associated with these bacteria include nitrogen fixation (6), soil phosphorus solubilization (9) and solubilizing insoluble potassium $(10,26)$. Research into the impact of PGPB has provided a greater understanding of the multiple facets of disease suppression by these biocontrol agents. Much remains to be learned from these bacteria that have unique associations and a more pronounced growthenhancing effect on host plants. Moreover, additional environmentally safe and economically feasible root-knot nematode control practices needs to be available $(7,14,27$, 32).

The main focus of this work was to evaluate the dual effect of some bacterial strains as biofertilizers and biocontrol agents against the root-knot nematode $M$. incognita infestation in sandy soil cultivated with tomato.

\section{MATERIALS}

\section{Bacterial biofertilizers and nematode used}

Strains of bacterial biofertilizers including nitrogen fixing bacteria (Paenibacillus polymyxa NFB2, NFB5, NFB6, NFB7), phosphate solubilizing bacteria (Bacillus megaterium PSB2, PSB4, PSB5), potassium solubilizing bacteria (B. circulans KSB2, KSB4, KSB7) and the root-knot nematode Meloidogyne incognita were isolated and identified by the authors in a previous work (8). Bacterial strains were maintained on nutrient agar slants at $4^{\circ} \mathrm{C}$, while pure culture of $M$. incognita was maintained on roots of tomato plants (Lycopersicon esculantium Mill cv. Castel Rock) growing in 20-cm diameter pots in sterile sandy-loam soil in greenhouse.

\section{Microbiological Media used}

a- Nutrient agar medium (12) was used to determine the total bacterial count. b- Soil extract agar medium (5) was used to determine the densities of spore forming bacteria. cModified Buntt and Rovira medium (16) was used for counting of phosphate solubilizing bacteria. d- Modified Aleksandrov's medium (34) was used for counting of potassium solubilizing bacteria. e- MBS medium (18) was used for counting of nitrogen fixing bacteria. On all media, counting was done by using the plate count method (12).

\section{Plant and soil used}

Thirty days old seedlings of tomato (Lycopersicon esculantium Mill cv. Castel Rock) were used as the host plant for $M$. incognita. They were kindly provided from Central Laboratory of Agricultural Climate, Agricultural Research Center, Dokki, Giza, Egypt. Seedlings were transplanted into 25-cm diameter plastic pots (one seedling/pot) filled with $5 \mathrm{~kg}$ of sterilized sandy soil. They were watered daily with tap water and with a nutrient solution once a week.

\section{Chemical fertilizers}

Ammonium sulfate $(20.5 \% \mathrm{~N})$, Potassium sulfate (48\% $\left.\mathrm{K}_{2} \mathrm{O}\right)$ and phosphoric acid $\left(80 \% \mathrm{P}_{2} \mathrm{O}_{5}\right)$ were used for nitrogen, potassium and phosphorus fertilization, respectively. Rock phosphate $\left(\begin{array}{lll}16.7 \% & \mathrm{P}_{2} \mathrm{O}_{5}\end{array}\right)$ and Feldspar (Potassium ore $11 \%$ $\mathrm{K}_{2} \mathrm{O}$ ) were used as cheap sources for phosphorus and potassium fertilizers. All chemical fertilizers were provided from Al-Ahram Company for Mining and Natural Fertilizers, Giza, Egypt. 


\section{METHODS}

\section{Preparation of bacterial inocula}

For each bacterial strain, a conical flask $(250 \mathrm{ml})$ containing $100 \mathrm{ml}$ of nutrient broth medium consisted of $5.0 \mathrm{~g}$ peptone, $3.0 \mathrm{~g}$ beef extract, $1000 \mathrm{ml}$ tap water, (pH was adjusted to 7.0) was inoculated and incubated at $28-30^{\circ} \mathrm{C}$ with shaking at $150 \mathrm{rpm}$ for two days prior to application.

\section{Preparation of $M$. incognita inoculum}

When nematode inoculum as the second stage juveniles $\left(J_{2 s}\right)$ was needed, galled tomato roots were washed thoroughly with tap water, cut into pieces then placed in mist chamber for egg hatching (23). The first catch was discarded, and the following emerged $J_{2 s}$ were collected daily and refrigerated at $6^{\circ} \mathrm{C}$ for the experimental use. $\mathrm{J}_{2 \mathrm{~s}}$ were placed in $0.5 \%$ sodium hypochlorite, agitated and rinsed with sterile water immediately before infestation (15).

\section{Greenhouse pot experiment}

Four days after seedlings transplantation, seedlings were infested with 1000 fresh $\mathrm{J}_{2 \mathrm{~s}} /$ plant in $10 \mathrm{ml}$ suspension. Two days later, each pot was inoculated with a single bacterial culture at the rate of $10 \mathrm{ml} /$ pot (containing $2 \times 10^{7} \mathrm{cfu} / \mathrm{ml}$ ). There were also two uninoculated controls: In uninoculated control 1, the nematode was applied but the bacteria were not, whilst in uninoculated control 2, neither the nematode nor the bacteria were applied. The inoculated plants were maintained in greenhouse for 60 days at $28 \pm 2{ }^{\circ} \mathrm{C}$. Throughout 60 days after bacterial inoculation, the plants were carefully removed from pots and the rhizosphere and soil of each pot were thoroughly mixed to compose representative samples then collected in labeled plastic bags for the determination of bacterial populations, $\mathrm{CO}_{2}$ evolution and second stage juveniles $\left(\mathrm{J}_{2 \mathrm{~s}}\right)$. Roots of plants taken 30 and 60 days post-bacterial inoculation were gently washed to remove soil particles for the determination of nematode population in roots. Plant growth was determined 60 days post-bacterial inoculation. The shoot length was measured from the soil line to the tip of the stem and expressed in $\mathrm{cm}$. The dry weight of shoots and roots was recorded after drying in oven at $70^{\circ} \mathrm{C}$. Nitrogen, phosphorus and potassium contents of tomato plants were determined according to Jackson (11). The rate of $\mathrm{CO}_{2}$ evolution was determined according to the method described by Shehata (25) and calculated according to Alef and Nannipieri (1). Ten replicates of each treatment were done and average response was taken. The obtained data were subjected to an analysis by using Statistical Analysis System (SAS) (version 6.12, SAS, Institute Inc., Cary, NC, USA). Duncan`s Multiple Range Test was used to test significance of means according to Snedecor and Cochran (29). Application treatments of this experiment are illustrated in Table (1).

Table 1. Application treatments of tomato plants infested with $M$. incognita and inoculated with different $P$. polymyxa, B. megaterium and B. circulans strains in potted sandy soil.

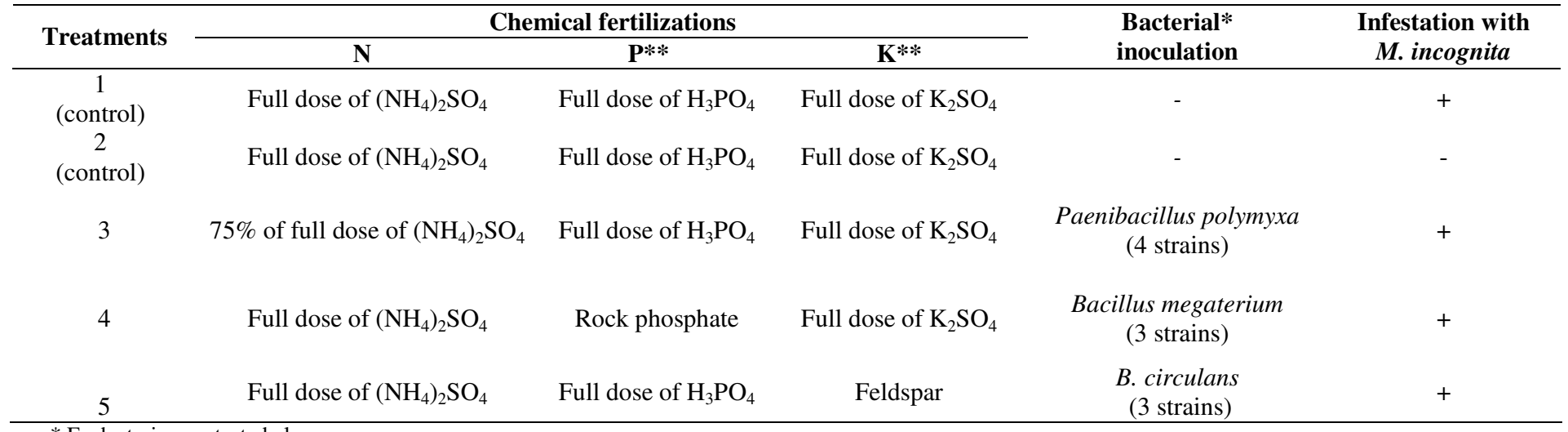

**Rock phosphate and feldspar were added in equivalent to $(\mathrm{P} \%, \mathrm{~K} \%)$ in full recommended dose of $\mathrm{H}_{3} \mathrm{PO}_{4}$ and $\mathrm{K}_{2} \mathrm{SO}_{4}$. 


\section{M. incognita measurements}

For counting of $\mathrm{J}_{2 \mathrm{~s}}$, the soil of each pot was mixed thoroughly and about $250 \mathrm{~g}$ of soil was used for nematode extraction by using the Baermann funnel technique (30). Extracted $\mathrm{J}_{2 \mathrm{~s}}$ were counted in $1 \mathrm{ml}$ suspension using counting slides. Number of $\mathbf{J}_{2 \mathrm{~s}}$ was attributed to $1 \mathrm{~kg}$ soil. Washed root was placed in a mist chamber for egg hatching (23). The hatched $\mathrm{J}_{2 \mathrm{~s}}$ were collected daily and refrigerated at $6^{\circ} \mathrm{C}$ for 5 days after which were counted. In one $\mathrm{ml}$ of extracted nematode suspension, $J_{2 s}$ were counted using nematodes counting slides. Roots were removed from the mist chamber and stained with acid fuchsin in cold lactophenol for more than $24 \mathrm{~h}$. The stained roots were rinsed with tap water and cut into pieces to facilitate counting of galls, females and egg masses using a stereomicroscope. The reduction of nematode population due to different bacterial inoculations was calculated compared with the uninoculated infested tomato control.

\section{RESULTS AND DISCUSSION}

The benefits of different bacterial inoculations on the growth of infested tomato plants with the root-knot nematode M. incognita, and their impact as biocontrol agents were studied. Within 60 days after tomato seedlings inoculation, the counts of bacterial strains were increasing (Table 2). The inoculation with $P$. polymyxa NFB7 exhibited the highest total nitrogen fixing bacterial (NFB) counts comparing with other $P$. polymyxa strains $\left(131 \times 10^{4}\right.$ and $172 \times 10^{4}$ cells / g dry soil after 30 and 60 days of inoculation, respectively). Also, this treatment achieved the highest total bacterial count and total bacterial spores count after 60 days of inoculation $\left(221 \times 10^{6}\right.$ and $195 \times 10^{5} / \mathrm{g}$ dry soil, respectively). Comparing with control 1, this treatment enhanced the growth of total bacteria and total bacterial spores populations after 60 days of inoculation by 2.6 and 1.89 folds, respectively. The $\mathrm{CO}_{2}$ evolution induced under the effect of $P$. polymyxa NFB7 inoculation were 13 and $19.6 \mathrm{mg} / \mathrm{g}$ dry soil / h, after 30 and 60 days, respectively.
Among B. megaterium and B. circulans strains inoculations, B. megaterium PSB2 and B. circulans KSB2 recorded the highest PSB and KSB counts $\left(130 \times 10^{4}, 190 \times\right.$ $10^{4}$ and $146 \times 10^{4}, 190 \times 10^{4} / \mathrm{g}$ dry soil after 30 and 60 days of inoculation, respectively (Table 2). The equivalent $\mathrm{CO}_{2}$ evolutions due to the inoculation with the two strains were 15.01, 18.3 and $15.41,19.4 \mathrm{mg} / \mathrm{g}$ dry soil / h, respectively. $B$. megaterium PSB2 and $B$. circulans KSB2 inoculations recorded the highest total bacterial count and total bacterial spores count after 60 days of inoculation $\left(104 \times 10^{6}, 193 \times 10^{5}\right.$ and $198 \times 10^{6}, 189 \times 10^{5} / \mathrm{g}$ dry soil, respectively), which represented 1.2, 1.87 and $1.5,1.83$ folds comparing with control 1. These results indicated that these bacterial biofertilizers persisted in soil up to 60 days after inoculation despite of the lack of organic matter and depending on the inorganic compounds used for plants fertilization.

By comparing the plant growth of uninoculated infested plants (control 1) with those of uninoculated uninfested plants (control 2), a great reduction was achieved (Table 3). The reduction in shoot length $(\mathrm{cm})$, number of leaves / plant, shoot dry weight / plant and root dry weight / plant were $21.2 \%, 13.3$ $\%, 23.7 \%$ and $17.4 \%$, respectively. The majority of bacterial strains inoculations resulted in prevention or even reduction of the consequences of nematode infection which reflected on increasing the plants growth comparing with control 1 (Table 3). The inoculation with P. polymyxa NFB7 achieved the most promising results. This treatment increased the shoot length (cm), number of leaves / plant, shoot dry weight $(\mathrm{g}) /$ plant and root dry weight (g) / plant by $32.6 \%, 30.8 \%, 70.3 \%$ and 14.2 $\%$, respectively. Lower percentages could be obtained if results were compared with those of uninfested plants (control 2) (4.4 $\%, 13.3 \%, 29.9 \%$ and $-5.6 \%$, respectively) (Table 3). B. megaterium PSB2 and B. circulans KSB2 inoculations were the most efficient among the other PSB and KSB strains. They increased the shoot length $(\mathrm{cm})$, number of leaves / plant, shoot dry weight (g) / plant, root dry weight (g) / plant comparing with uninoculated infested plants (control 1) by $25.6 \%, 15.4$ $\%, 29.2 \%, 3.8 \%$ and $2.3 \%, 7.7 \%, 66.8 \%, 9.7 \%$, respectively. The root weight was not relevant to the weight of 
the shoot. This could be due to root galling on infested plants

mechanisms due to the interaction between the host, the and induced systemic resistance or multiple potential defense

bacteria, and the nematode (33).

Table 2. Bacterial activity and $\mathrm{CO}_{2}$ evolution per gram of dry potted soil of tomato plants infested with M. incognita and inoculated with different $P$. polymyxa, B. megaterium and B. circulans strains in sandy soil.

\begin{tabular}{|c|c|c|c|c|c|c|c|}
\hline Treatments & $\begin{array}{c}\text { Time after } \\
\text { bacterial } \\
\text { inoculation } \\
\text { (days) }\end{array}$ & $\begin{array}{c}\text { Total } \\
\text { bacterial } \\
\text { count / g dry } \\
\text { soil }(\mathbf{x 1 0})\end{array}$ & $\begin{array}{c}\text { Total spores } \\
\text { count / g dry } \\
\text { soil }\left(\mathbf{x 1 0}^{5}\right)\end{array}$ & $\begin{array}{l}\text { Nitrogen fixing } \\
\text { bacterial count } \\
\text { / g dry soil } \\
\left(\mathbf{x 1 0}^{4}\right)\end{array}$ & $\begin{array}{c}\text { Phosphate } \\
\text { solubilizing } \\
\text { bacterial } \\
\text { count / g dry } \\
\text { soil }\left(\mathbf{x 1 0}^{4}\right)\end{array}$ & $\begin{array}{c}\text { Potassium } \\
\text { solubilizing } \\
\text { bacterial } \\
\text { count / g dry } \\
\text { soil }\left(\mathbf{x 1 0}^{4}\right)\end{array}$ & $\begin{array}{c}\mathrm{CO}_{2} \text { evolution } \\
\text { (mg/g dry } \\
\text { soil/h) }\end{array}$ \\
\hline \multirow{3}{*}{ Control(1)* } & 0 & $55^{\mathrm{d}}$ & $55^{\mathrm{d}}$ & $28^{\mathrm{e}}$ & $35^{\mathrm{d}}$ & $45^{\mathrm{d}}$ & $4.13^{\mathrm{d}}$ \\
\hline & 30 & $73^{\mathrm{f}}$ & $71^{\mathrm{i}}$ & $54^{\mathrm{e}}$ & $54^{\mathrm{d}}$ & $92^{\mathrm{d}}$ & $8.2^{\mathrm{d}}$ \\
\hline & 60 & $85^{\mathrm{hi}}$ & $103^{\mathrm{f}}$ & $133^{\mathrm{c}}$ & $73^{\mathrm{c}}$ & $132^{\mathrm{d}}$ & $9.2^{\mathrm{e}}$ \\
\hline P. polymyxa & 0 & $28^{\mathrm{g}}$ & $73^{\mathrm{b}}$ & $42^{\mathrm{d}}$ & - & - & $2.8^{\mathrm{e}}$ \\
\hline \multirow[t]{2}{*}{ NFB2 } & 30 & $82^{\mathrm{e}}$ & $104^{\mathrm{fg}}$ & $82^{\mathrm{d}}$ & - & - & $8.2^{\mathrm{d}}$ \\
\hline & 60 & $123^{\mathrm{d}}$ & $132^{\mathrm{e}}$ & $122^{\mathrm{d}}$ & - & - & $12.6^{\mathrm{d}}$ \\
\hline \multirow{3}{*}{ NFB5 } & 0 & $63^{c}$ & $63^{\mathrm{c}}$ & $56^{\mathrm{c}}$ & - & - & $6.3^{\mathrm{c}}$ \\
\hline & 30 & $102^{\mathrm{c}}$ & $98^{\mathrm{g}}$ & $110^{\mathrm{c}}$ & - & - & $10^{\mathrm{c}}$ \\
\hline & 60 & $173^{\mathrm{c}}$ & $153^{\mathrm{d}}$ & $146^{\mathrm{b}}$ & - & - & $17.7^{\mathrm{ab}}$ \\
\hline \multirow{3}{*}{ NFB6 } & 0 & $73^{\mathrm{b}}$ & $82^{\mathrm{a}}$ & $76^{\mathrm{b}}$ & - & - & $7.3^{\mathrm{bc}}$ \\
\hline & 30 & $114^{\mathrm{b}}$ & $106^{\mathrm{ef}}$ & $115^{\mathrm{b}}$ & - & - & $11.5^{\mathrm{c}}$ \\
\hline & 60 & $198^{\mathrm{b}}$ & $165^{\mathrm{c}}$ & $169^{\mathrm{a}}$ & - & - & $15.5^{\mathrm{c}}$ \\
\hline \multirow{3}{*}{ NFB7 } & 0 & $85^{\mathrm{a}}$ & $85^{\mathrm{a}}$ & $84^{\mathrm{a}}$ & - & - & $8.5^{\mathrm{b}}$ \\
\hline & 30 & $129^{\mathrm{a}}$ & $116^{\mathrm{d}}$ & $131^{\mathrm{a}}$ & - & - & $13^{\mathrm{b}}$ \\
\hline & 60 & $221^{\mathrm{a}}$ & $195^{\mathrm{a}}$ & $172^{\mathrm{a}}$ & - & - & $19.6^{\mathrm{a}}$ \\
\hline B. megaterium & 0 & $54^{\mathrm{d}}$ & $87^{\mathrm{a}}$ & - & $61^{\mathrm{b}}$ & - & $10.48^{\mathrm{a}}$ \\
\hline \multirow{3}{*}{ PSB2 } & 30 & $81^{\mathrm{e}}$ & $162^{\mathrm{a}}$ & - & $130^{\mathrm{a}}$ & - & $15.01^{\mathrm{a}}$ \\
\hline & 60 & $104^{\mathrm{g}}$ & $193^{\mathrm{a}}$ & - & $190^{\mathrm{a}}$ & - & $18.3^{\mathrm{a}}$ \\
\hline & 0 & $36^{\mathrm{f}}$ & $73^{b}$ & - & $51^{\mathrm{c}}$ & - & $8.17^{\mathrm{b}}$ \\
\hline \multirow[t]{2}{*}{ PSB4 } & 30 & $63^{g}$ & $142^{\mathrm{b}}$ & - & $115^{\mathrm{b}}$ & - & $13.48^{\mathrm{b}}$ \\
\hline & 60 & $91^{\mathrm{h}}$ & $174^{\mathrm{b}}$ & - & $163^{\mathrm{b}}$ & - & $16.1^{\mathrm{b}}$ \\
\hline \multirow{3}{*}{ PSB5 } & 0 & $46^{\mathrm{e}}$ & $61^{\mathrm{c}}$ & - & $72^{\mathrm{a}}$ & - & $10.48^{\mathrm{a}}$ \\
\hline & 30 & $75^{\mathrm{f}}$ & $90^{\mathrm{h}}$ & - & $94^{\mathrm{c}}$ & - & $8.23^{\mathrm{d}}$ \\
\hline & 60 & $83^{\mathrm{i}}$ & $131^{\mathrm{e}}$ & - & $166^{\mathrm{b}}$ & - & $11.9^{\mathrm{d}}$ \\
\hline B. circulans & 0 & $89^{\mathrm{a}}$ & $82^{\mathrm{a}}$ & - & - & $100^{\mathrm{a}}$ & $8.14^{\mathrm{b}}$ \\
\hline \multirow[t]{2}{*}{ KSB2 } & 30 & $132^{\mathrm{a}}$ & $134^{\mathrm{c}}$ & - & - & $146^{\mathrm{a}}$ & $15.41^{\mathrm{a}}$ \\
\hline & 60 & $198^{\mathrm{b}}$ & $189^{\mathrm{a}}$ & - & - & $190^{\mathrm{a}}$ & $19.4^{\mathrm{a}}$ \\
\hline \multirow{3}{*}{ KSB4 } & 0 & $65^{\mathrm{c}}$ & $63^{c}$ & - & - & $76^{\mathrm{b}}$ & $5.62^{\mathrm{cd}}$ \\
\hline & 30 & $74^{\mathrm{f}}$ & $112^{\mathrm{e}}$ & - & - & $105^{\mathrm{c}}$ & $12.45^{\mathrm{bc}}$ \\
\hline & 60 & $124^{\mathrm{e}}$ & $153^{\mathrm{d}}$ & - & - & $165^{\mathrm{b}}$ & $17.74^{\mathrm{ab}}$ \\
\hline \multirow{3}{*}{ KSB7 } & 0 & $44^{\mathrm{e}}$ & $73^{b}$ & - & - & $63^{c}$ & $7.01^{\mathrm{bc}}$ \\
\hline & 30 & $88^{\mathrm{d}}$ & $123^{\mathrm{d}}$ & - & - & $124^{\mathrm{b}}$ & $13.21^{\mathrm{b}}$ \\
\hline & 60 & $116^{\mathrm{f}}$ & $174^{\mathrm{b}}$ & - & - & $153^{\mathrm{c}}$ & $15.96^{\mathrm{bc}}$ \\
\hline
\end{tabular}

* Uninoculated tomato plants infested with $M$. incognita were supplemented with full-dose of chemical NPK fertilizers before transplantation.

Means within the same column not followed by the same letter are significantly different $(\mathrm{P}<0.05)$. 
Table 3. Effect of various bacterial biofertilizers treatments on growth of tomato plants infested with $M$. incognita 60 days postinoculation.

\begin{tabular}{|c|c|c|c|c|c|c|c|c|c|c|}
\hline \multirow{3}{*}{ Treatments } & \multicolumn{10}{|c|}{ Growth parameters } \\
\hline & \multirow{2}{*}{$\begin{array}{c}\text { Shoot } \\
\text { length } \\
\text { (cm) }\end{array}$} & \multirow{2}{*}{$\begin{array}{l}\text { No. of } \\
\text { leaves / } \\
\text { plant }\end{array}$} & \multirow{2}{*}{$\begin{array}{l}\text { Shoot dry } \\
\text { weight } \\
\text { (g/ plant) }\end{array}$} & \multirow{2}{*}{$\begin{array}{c}\text { Root dry } \\
\text { weight } \\
\text { (g/ plant) }\end{array}$} & \multicolumn{3}{|c|}{ Shoot content $(\%)$} & \multicolumn{3}{|c|}{ Root content (\%) } \\
\hline & & & & & $\mathbf{N}$ & $\mathbf{P}$ & $\mathbf{K}$ & $\mathbf{N}$ & $\mathbf{P}$ & $\mathbf{K}$ \\
\hline \multicolumn{11}{|l|}{ P. polymyxa } \\
\hline NFB2 & $44.1^{\mathrm{e}}$ & $11^{\mathrm{e}}$ & $3.12^{\mathrm{h}}$ & $2.21^{\mathrm{c}}$ & $1.23^{\mathrm{e}}$ & $0.62^{\mathrm{ab}}$ & $1.46^{\mathrm{c}}$ & $0.26^{\mathrm{e}}$ & $0.43^{\mathrm{b}}$ & $0.30^{\circ}$ \\
\hline NFB5 & $46.6^{\mathrm{d}}$ & $15^{\mathrm{bc}}$ & $6.11^{\mathrm{f}}$ & $3.18^{\mathrm{b}}$ & $2.2^{\mathrm{a}}$ & $0.61^{\mathrm{b}}$ & $1.45^{\mathrm{cd}}$ & $0.52^{\mathrm{b}}$ & $0.42^{\mathrm{b}}$ & $0.18^{\mathrm{f}}$ \\
\hline NFB6 & $54^{\mathrm{b}}$ & $15^{\mathrm{b}}$ & $10.25^{\mathrm{b}}$ & $4.01^{\mathrm{a}}$ & $1.43^{\mathrm{d}}$ & $0.53^{\mathrm{c}}$ & $1.03^{\mathrm{e}}$ & $0.26^{\mathrm{e}}$ & $0.38^{\mathrm{d}}$ & $0.37^{\mathrm{b}}$ \\
\hline NFB7 & $57^{\mathrm{a}}$ & $17^{\mathrm{a}}$ & $11.63^{\mathrm{a}}$ & $4.01^{\mathrm{a}}$ & $2.32^{\mathrm{a}}$ & $0.63^{\mathrm{a}}$ & $1.53^{\mathrm{b}}$ & $0.58^{\mathrm{a}}$ & $0.47^{\mathrm{a}}$ & $0.40^{\circ}$ \\
\hline \multicolumn{11}{|l|}{ B. megaterium } \\
\hline PSB2 & $54^{\mathrm{bc}}$ & $15^{\mathrm{b}}$ & $8.82^{c}$ & $3.64^{\mathrm{b}}$ & $2.2^{\mathrm{a}}$ & $0.61^{b}$ & $1.46^{\mathrm{c}}$ & $0.48^{\mathrm{c}}$ & $0.43^{\mathrm{b}}$ & $0.36^{\mathrm{b}}$ \\
\hline PSB4 & $52^{c}$ & $13^{\mathrm{cd}}$ & $5.14^{\mathrm{g}}$ & $2.04^{c}$ & $1.82^{\mathrm{c}}$ & $0.51^{\mathrm{a}}$ & $1.64^{\mathrm{a}}$ & $0.46^{\mathrm{c}}$ & $0.41^{\mathrm{bc}}$ & $0.23^{\mathrm{e}}$ \\
\hline PSB5 & $53^{c}$ & $12^{\mathrm{d}}$ & $6.02^{f}$ & $2.5^{\mathrm{c}}$ & $2.20^{\mathrm{a}}$ & $0.55^{\mathrm{c}}$ & $1.43^{\mathrm{cd}}$ & $0.32^{\mathrm{d}}$ & $0.41^{\mathrm{bc}}$ & $0.23^{\mathrm{e}}$ \\
\hline \multicolumn{11}{|l|}{ B. circulans } \\
\hline KSB2 & $44^{\mathrm{e}}$ & $14^{\mathrm{bc}}$ & $11.39^{\mathrm{a}}$ & $3.85^{\mathrm{a}}$ & $2.38^{\mathrm{a}}$ & $0.65^{\mathrm{a}}$ & $1.44^{\mathrm{cd}}$ & $0.54^{\mathrm{b}}$ & $0.44^{\mathrm{b}}$ & $0.39^{\mathrm{a}}$ \\
\hline KSB4 & $38^{\mathrm{g}}$ & $13^{\mathrm{cd}}$ & $7.02^{\text {ed }}$ & $1.06^{\mathrm{d}}$ & $2.22^{\mathrm{a}}$ & $0.52^{c}$ & $1.39^{\mathrm{d}}$ & $0.51^{\mathrm{b}}$ & $0.43^{\mathrm{b}}$ & $0.28^{\circ}$ \\
\hline KSB7 & $42^{\mathrm{f}}$ & $13^{\mathrm{cd}}$ & $6.14^{\mathrm{fe}}$ & $2.21^{\mathrm{c}}$ & $1.89^{c}$ & $0.56^{\mathrm{c}}$ & $1.09^{\mathrm{e}}$ & $0.46^{\mathrm{c}}$ & $0.42^{\mathrm{b}}$ & $0.18^{f}$ \\
\hline Control(1) & $43^{\mathrm{e}}$ & $13^{\mathrm{cd}}$ & $6.83^{\mathrm{d}}$ & $3.51^{\mathrm{b}}$ & $2.17^{\mathrm{b}}$ & $0.53^{\mathrm{c}}$ & $1.46^{\mathrm{c}}$ & $0.52^{b}$ & $0.42^{\mathrm{b}}$ & $0.35^{\mathrm{b}}$ \\
\hline Control(2) & $54.6^{\mathrm{b}}$ & $15^{\mathrm{b}}$ & $8.95^{\mathrm{c}}$ & $4.25^{\mathrm{d}}$ & $2.24^{\mathrm{a}}$ & $0.61^{\mathrm{b}}$ & $1.48^{\mathrm{c}}$ & $0.54^{\mathrm{b}}$ & $0.43^{\mathrm{b}}$ & $0.39^{\circ}$ \\
\hline
\end{tabular}

Control (1): Uninoculated tomato plants infested with $M$. incognita were supplemented with full-dose of chemical NPK fertilizers before transplantation. Control (2): Uninoculated uninfested tomato plants were supplemented with full-dose of chemical NPK fertilizers before transplantation.

Means within the same column not followed by the same letter are significantly different $(\mathrm{P}<0.05)$.

N P K contents of inoculated plants by any bacterial strain gave close or in some cases slightly higher determinations comparing with control 1 (Table 3). P. polymyxa NFB7, B. megaterium PSB2 and B. circulans KSB2 inoculations achieved the highest N P K contents. P. polymyxa NFB7 increased the N P K contents of shoots by $6.91 \%, 65.86 \%$, $41.20 \%$ and roots by $11.5 \%, 11.9 \%, 14.2 \%$, respectively. Bacterial inoculations induced tomato plants to endure the nematode infection, N P K contents of endured plants were in general close to those of uninfested plants (control 2).

Regarding to the effectiveness of the strains of bacterial biofertilizers in suppressing $M$. incognita reproduction, it could be observed that, most of bacterial inoculations had significantly reduced nematode population by comparing with the uninoculated infested plants (control 1), especially for the counts of hatched $\mathrm{J}_{2 \mathrm{~s}} /$ root, females/root and $\mathrm{J}_{2 \mathrm{~s}} / 1 \mathrm{~kg}$ soil (Table 4). The reduction in nematode population was more obvious after 60 days of inoculation by most inoculated treatments. However, inoculating $P$. polymyxa NFB7, B. megaterium PSB2 and $B$. circulans KSB2 resulted in the highest control effect comparing with control 1. After 30 days of inoculation, they recorded the highest reduction in numbers of females/root by $14.3 \%$, hatched $\mathrm{J}_{2 \mathrm{~s}} /$ root by $87.2 \%$ and in $\mathrm{J}_{2 \mathrm{~s}} / 1 \mathrm{~kg}$ soil by $79.3 \%$, respectively (Table 5). While, after sixty days of inoculation, the highest reduction by the three biofertilizers were obtained on numbers of hatched $\mathrm{J}_{2 \mathrm{~s}} /$ root $(95.8 \%)$, females/root $(63.75 \%)$ and $\mathrm{J}_{2 \mathrm{~s}} / 1 \mathrm{~kg}$ soil (57.8\%), respectively (Table 5).

The present pot experiment indicated that bacterial biofertilizers reduced significantly the ability of $M$. incognita to reproduce in soil which was a strain dependant. Several reports were focused on the benefits of rhizosphere colonizing bacteria especially nitrogen fixing bacteria (NFB), phosphate solubilizing bacteria (PSB) and potassium solubilizing bacteria (KSB) as biocontrol agents, some of important genera include Agrobacterium, Alcaligenes, Bacillus, Clostridium, Desulfovibrio, Pseudomonas, Serratia, Paenibacillus and Streptomyces. Application of these bacteria has given very promising results $(28,13,14)$. Whole cultures and supernatants (exotoxins) of Bacillus thuringiensis subsp. Brasiliensis and B. laterosporus caused high mortality of Meloidogyne javanica in in-vitro bioassays and greenhouse tests on tomato (4). Neipp and Becker (19) reported that several strains of B. megaterium 
were found to be effective against Heterodera schachtii, they reduced $\mathrm{J}_{2 \mathrm{~s}}$ penetration of sugar beet by $38 \%-59 \%$. Similarly, $B$. megaterium was reported to reduce by $50 \%$ the penetration of both M. chitwoodi and Pratylenchus penetrans in potato (2). Padgham and Sikora (20) found that the inoculation with $B$. megaterium reduced more than $40 \%$ of nematode penetration and gall formation compared with non-treated rice root. In a separate study, colonization of rice roots with $B$. megaterium decreased migration of $M$. graminicola to the root zone by nearly $60 \%$, compared with that of nontreated roots. Exposure of $M$. graminicola eggs to secondary metabolites of $B$. megaterium reduced hatching eggs by over $60 \%$ compared with eggs not exposed to the bacteria.

Table 4. Effect of different biofertilizers strains inoculations on $M$. incognita infestation throughout 60 days post-inoculation in sandy soil.

\begin{tabular}{|c|c|c|c|c|c|c|}
\hline \multirow[b]{2}{*}{ Treatments } & \multirow{2}{*}{$\begin{array}{c}\text { Time after bacterial } \\
\text { inoculation } \\
\text { (days) }\end{array}$} & \multicolumn{5}{|c|}{ M. incognita measurements } \\
\hline & & $\begin{array}{c}\text { No. of galls } \\
\text { / root }\end{array}$ & $\begin{array}{c}\text { No. of egg } \\
\text { masses / root }\end{array}$ & $\begin{array}{c}\text { No. of hatched } \\
\mathbf{J}_{2 \mathrm{~s}} / \text { root }\end{array}$ & $\begin{array}{c}\text { No. of females } \\
/ \text { root }\end{array}$ & $\begin{array}{l}\text { No. of } \mathbf{J}_{2 \mathrm{~s}} \\
/ 1 \mathrm{~kg} \text { soil }\end{array}$ \\
\hline $\begin{array}{l}P . \text { polymyxa } \\
\text { NFB2 }\end{array}$ & $\begin{array}{l}30 \\
60\end{array}$ & $\begin{array}{r}135^{\mathrm{f}} \\
56^{\mathrm{b}}\end{array}$ & $\begin{array}{l}79^{\mathrm{e}} \\
31^{\mathrm{a}}\end{array}$ & $\begin{array}{l}8790^{\mathrm{h}} \\
990^{\mathrm{c}}\end{array}$ & $\begin{array}{l}64^{\mathrm{d}} \\
18^{\mathrm{a}}\end{array}$ & $\begin{array}{l}16200^{\mathrm{i}} \\
4800^{\mathrm{b}}\end{array}$ \\
\hline NFB5 & $\begin{array}{l}30 \\
60\end{array}$ & $\begin{array}{l}76^{\mathrm{bc}} \\
60^{\mathrm{b}}\end{array}$ & $\begin{array}{l}49^{\mathrm{bc}} \\
36^{\mathrm{a}}\end{array}$ & $\begin{array}{l}6060^{\mathrm{g}} \\
2580^{\mathrm{d}}\end{array}$ & $\begin{array}{l}35^{\mathrm{b}} \\
22^{\mathrm{a}}\end{array}$ & $\begin{array}{l}11880^{\mathrm{g}} \\
9240^{\mathrm{d}}\end{array}$ \\
\hline NFB6 & $\begin{array}{l}30 \\
60\end{array}$ & $\begin{array}{l}89^{d} \\
66^{b c}\end{array}$ & $\begin{array}{l}62^{\mathrm{d}} \\
35^{\mathrm{a}}\end{array}$ & $\begin{array}{l}6960^{\mathrm{g}} \\
3300^{\mathrm{e}}\end{array}$ & $\begin{array}{l}49^{\mathrm{c}} \\
25^{\mathrm{ab}}\end{array}$ & $\begin{array}{l}12240^{\mathrm{h}} \\
5760^{\mathrm{c}}\end{array}$ \\
\hline NFB7 & $\begin{array}{l}30 \\
60\end{array}$ & $\begin{array}{l}63^{\mathrm{b}} \\
41^{\mathrm{a}}\end{array}$ & $\begin{array}{l}40^{\mathrm{b}} \\
28^{\mathrm{a}}\end{array}$ & $\begin{array}{l}4050^{\mathrm{f}} \\
390^{\mathrm{b}}\end{array}$ & $\begin{array}{l}30^{\mathrm{b}} \\
12^{\mathrm{a}}\end{array}$ & $\begin{array}{c}10560^{\mathrm{f}} \\
1452^{\mathrm{a}}\end{array}$ \\
\hline $\begin{array}{l}\text { B. megaterium } \\
\text { PSB2 }\end{array}$ & $\begin{array}{l}30 \\
60\end{array}$ & $\begin{array}{l}50^{\mathrm{a}} \\
70^{\mathrm{c}}\end{array}$ & $\begin{array}{l}26^{\mathrm{a}} \\
44^{\mathrm{b}}\end{array}$ & $\begin{array}{l}360^{\mathrm{a}} \\
4980^{\mathrm{f}}\end{array}$ & $\begin{array}{l}22^{\mathrm{a}} \\
29^{\mathrm{b}}\end{array}$ & $\begin{array}{c}1560^{\mathrm{a}} \\
11000^{\mathrm{e}}\end{array}$ \\
\hline PSB4 & $\begin{array}{l}30 \\
60\end{array}$ & $\begin{array}{l}67^{\mathrm{b}} \\
89^{\mathrm{d}}\end{array}$ & $\begin{array}{l}41^{\mathrm{b}} \\
59^{\mathrm{bc}}\end{array}$ & $\begin{array}{c}690^{\mathrm{b}} \\
7980^{\mathrm{i}}\end{array}$ & $\begin{array}{l}50^{\mathrm{c}} \\
52^{\mathrm{c}}\end{array}$ & $\begin{array}{c}4670^{\mathrm{d}} \\
17450^{\mathrm{h}}\end{array}$ \\
\hline PSB5 & $\begin{array}{l}30 \\
60\end{array}$ & $\begin{array}{l}61^{\mathrm{b}} \\
82^{\mathrm{d}}\end{array}$ & $\begin{array}{l}35^{\mathrm{b}} \\
56^{\mathrm{b}}\end{array}$ & $\begin{array}{c}660^{\mathrm{b}} \\
5970^{\mathrm{h}}\end{array}$ & $\begin{array}{l}40 b^{c} \\
33^{b}\end{array}$ & $\begin{array}{c}3480^{\mathrm{c}} \\
14660^{\mathrm{g}}\end{array}$ \\
\hline $\begin{array}{l}\text { B. circulans } \\
\text { KSB2 }\end{array}$ & $\begin{array}{l}30 \\
60\end{array}$ & $\begin{array}{l}68^{\mathrm{b}} \\
88^{\mathrm{d}}\end{array}$ & $\begin{array}{l}44^{\mathrm{b}} \\
49^{\mathrm{b}}\end{array}$ & $\begin{array}{l}1320^{\mathrm{c}} \\
5490^{\mathrm{g}}\end{array}$ & $\begin{array}{l}15^{\mathrm{a}} \\
47^{\mathrm{c}}\end{array}$ & $\begin{array}{l}2520^{b} \\
12650^{f}\end{array}$ \\
\hline KSB4 & $\begin{array}{l}30 \\
60\end{array}$ & $\begin{array}{l}92^{\mathrm{d}} \\
112^{\mathrm{e}}\end{array}$ & $\begin{array}{l}60^{\mathrm{d}} \\
80^{\mathrm{d}}\end{array}$ & $\begin{array}{c}2280^{\mathrm{d}} \\
296^{\mathrm{a}}\end{array}$ & $\begin{array}{l}22^{\mathrm{a}} \\
55^{\mathrm{cd}}\end{array}$ & $\begin{array}{l}8760^{\mathrm{e}} \\
19230^{\mathrm{i}}\end{array}$ \\
\hline KSB7 & $\begin{array}{l}30 \\
60\end{array}$ & $\begin{array}{l}102^{\mathrm{e}} \\
123^{\mathrm{f}}\end{array}$ & $\begin{array}{l}65^{\mathrm{d}} \\
83^{\mathrm{d}}\end{array}$ & $\begin{array}{l}2970^{\mathrm{e}} \\
9900^{\mathrm{k}}\end{array}$ & $\begin{array}{l}26^{\mathrm{ab}} \\
70^{\mathrm{e}}\end{array}$ & $\begin{array}{l}22600^{\mathrm{j}} \\
26400^{\mathrm{j}}\end{array}$ \\
\hline Control $(1)^{*}$ & $\begin{array}{l}30 \\
60\end{array}$ & $\begin{array}{c}71^{\mathrm{b}} \\
133^{\mathrm{g}}\end{array}$ & $\begin{array}{l}46^{\mathrm{b}} \\
86^{\mathrm{d}}\end{array}$ & $\begin{array}{l}4050^{f} \\
9360^{j}\end{array}$ & $\begin{array}{l}35^{b} \\
80^{f}\end{array}$ & $\begin{array}{l}12180^{\mathrm{h}} \\
30000^{\mathrm{k}}\end{array}$ \\
\hline
\end{tabular}

* Uninoculated tomato plants infested with Meloidogyne incognita were supplemented with full-dose of chemical NPK fertilizers before transplantation. Means within the same column not followed by the same letter are significantly different $(\mathrm{P}<0.05)$. 
Table 5. Effect of the most efficient biofertilizer strains treatments on nematode population after 30 and 60 days of inoculation comparing with control $1 *$.

\begin{tabular}{|c|c|c|c|c|c|c|}
\hline \multirow[b]{2}{*}{ Treatments } & \multirow{2}{*}{$\begin{array}{c}\text { Time after bacterial } \\
\text { inoculation } \\
\text { (days) }\end{array}$} & \multicolumn{5}{|c|}{ Reduction of nematode population } \\
\hline & & $\begin{array}{c}\text { No. of galls } \\
\text { / root }\end{array}$ & $\begin{array}{c}\text { No. of egg } \\
\text { masses / root }\end{array}$ & $\begin{array}{c}\text { No. of hatched } \\
\mathbf{J}_{2 \mathrm{~s}} / \text { root }\end{array}$ & $\begin{array}{c}\text { No. of females } \\
\text { / root }\end{array}$ & $\begin{array}{l}\text { No. of } \mathbf{J}_{2 \mathrm{~s}} \\
/ 1 \mathrm{~kg} \text { soil }\end{array}$ \\
\hline P. polymyxa & 30 & 11.3 & 13 & 0 & 14.3 & 13.3 \\
\hline NFB7 & 60 & 69.2 & 67.4 & 95.8 & 85 & 95.16 \\
\hline B. megaterium & 30 & 1.4 & 4.3 & 23 & 17.1 & 87.2 \\
\hline PSB2 & 60 & 47.4 & 48.8 & 46.8 & 63.75 & 63.3 \\
\hline B. circulans & 30 & 4.2 & 4.3 & 67.4 & 57.1 & 79.3 \\
\hline KSB2 & 60 & 33.8 & 43 & 41.3 & 41.25 & 57.8 \\
\hline
\end{tabular}

*Control 1: Uninoculated tomato plants infested with $M$. incognita were supplemented with full-dose of chemical NPK fertilizers before transplantation.

\section{CONCLUSIONS}

The present greenhouse pot experiment indicated that the individual inoculations of the bacterial biofertilizers $P$. polymyxa NFB7, B. megaterium PSB2 and B. circulans KSB2, enhanced significantly the growth of tomato plants, and suppressed the nematode population in infested plants roots and soil. Such effect was prolonged and increased through the 60 days after plant transplantation. Depending on these results, the combined addition of these bacterial cultures may be more effective to increase the nematode suppression in infested plants. The reliance on bacterial biofertilizers that have the ability to fix nitrogen or solubilize either insoluble phosphate or potassium, in the biological control of root-knot nematode helps in the same way to minimize the quantities of chemical nitrogen fertilizers used and may open the door for a wide application of cheap and more available crude sources of insoluble phosphate and potassium in agriculture.

\section{REFERENCES}

1. Alef, K.; Nannipieri, P.; 1995. Methods in applied soil microbiology and biochemistry. Academic Press, Harcourt Brace and Company Publishers, London, 214-217.

2. Al-Rehiayani, S.; Hafez, S.L.; Thorton, M.; Sandararaj, P. (1999). Effects of Pratylenchus neglectus, Bacillus megaterium, and oil radish or rapeseed green manure on reproductive potential of Meloidogyne sp. chitwoodi on potato. Nematropica 29, 37-49.

3. Bakshi, R.H.K. (2005). Integrated pest management: means for sustainable Agricultural development in the developing countries. Pakistan J. Social Sci. 3, 603-613.

4. Carneiro, R.M.D.G.; Desouza, I.S.; Belarmino, L.C. (1998). Nematicidal activity of Bacillus spp. strains on juveniles of Meloidogyne javanica. Nematol. Brasileira 22, 12-21.

5. Clark, F.E. (1965). Agar plate methods for total microbial count. In: Methods of Soil analysis. Part 2, Am. Soc. of Agronomy Inc., Madison, Wis., USA, 1460-1466.

6. Coelho, M.R.R.; von der Weid, I.; Zahner, V.; Seldin, L. (2003). Characterization of nitrogen-fixing Paenibacillus species by polymerase chain reaction-restriction fragment length polymorphism analysis of part of genes encoding $16 \mathrm{~S}$ rRNA and 23S rRNA and by multilocus enzyme electrophoresis. FEMS Microbiol. Lett. 222, 243-250.

7. Compant, S.; Duffy, B.; Nowak, J.; Clement, C.; Barka, E.A. (2005). Use of plant growth-promoting bacteria for biocontrol of plant diseases: Principles, mechanisms of action, and future prospects. Appl. Environ. Microbiol. 71, 4951-4959.

8. El-Hadad, M.E.; Mustafa, M.I.; Selim, Sh. M.; Mahgoob, A.E.A.; ElTayeb, T.S.; Abdel Aziz, Norhan H. (2010). In vitro evaluation of some bacterial isolates as biofertilizers and biocontrol agents against the second stage juveniles of Meloidogyne incognita. World J. Microbiol. Biotechnol. 26, 2249 - 2256.

9. Gen-Fu, W.; Xue-Ping, Z. (2005). Characterization of phosphorusreleasing bacteria in a small eutrophic shallow lake, Eastern China. Water Res. 39, 4623-4632.

10. Hu, X.; Chen, J.; Guo, J. (2006). Two Phosphate- and Potassiumsolubilizing Bacteria Isolated from Tianmu Mountain, Zhejiang, China. World J. Microbiol Biotechnol. 22, 983-990.

11. Jackson, M.L. (1973). Soil Chemical Analysis. Prentice Hall of India Private Limited, New Delhi, India.

12. Jacobs, M.B.; Gerstein, M.J. (1960). Handbook of Microbiology. Nostrand, D.V. (Ed.) Co., Inc., New York, 139-202.

13. Khan, Z.; Kim, S.G., Jeon, Y.H.; Khan, H.U.; Son, S.H.; Kim, Y.H. 
14. (2008). A plant growth promoting rhizobacterium, Paenibacillus polymyxa strain GBR-1, suppresses root-knot nematode. Bioresour. technol. 99, 3016-3023.

15. Khan, Z.; Kim, Y.H.; Kim, S.G.; Kim, H.W. (2007). Observations on the suppression of root-knot nematode Meloidogyne arenaria on tomato by incorporation of cyanobacteria powder Oscillatoria chlorine into potting field soil. Bioresour. Technol. 98, 69-73.

16. Kim, D.G.; Riggs, R.D. (1991). Characteristics and efficacy of a sterile hyphomycete (ARF 18), a new biocontrol agent for Heterodera glycines and other nematodes. J. Nematol. 23, 275-282.

17. Mahmoud, S.A.Z.; Abdel-Hafez, A.M.; EI-Sawy, M.; Hanafy, E.A. (1976). Efficiency of phosphate mobilizing bacteria on different phosphorus substrates in clay loamy soil. Egy. J. Soil. Sci. 16, 9-20.

18. Manzanilla, R.H.; Kenneth, E.; Bridge, J. (2004). Plant diseases caused by nematodes. In: Chen, Z.X.; Chen, S.Y.; Dickson, D.W. (eds.), Nematology Management and Utilization. Tsinghua University Press, CABI Publishing. pp. 637-716.

19. Mohamed, A.A. (2001). Studies on Some Asymbiotic $N_{2}$ Fixing Bacteria. M.Sc. Thesis, Fac. Agric., Ain Shams Univ., Egypt.

20. Neipp, P.W.; Becker, J.O. (1999). Evaluation of biocontrol activity of rhizobacteria from Beta vulgaris against Heterodora schachtii. J. Nematol. 31, 54-61.

21. Padgham, J.L.; Sikora, R.A. (2007). Biological control potential and modes of action of Bacillus megaterium against Meloidogyne graminicola on rice. Crop prot. 26, 971-977.

22. Rajendran, G.; Saritha, V. (2005). Effect of plant extract and their potential doses against root- knot nematode, Meloidogyne incognita on tomato. Ind. J. Nematol. 35, 38-41.

23. Randhawa, N.; Sakhuja, P.K.; Singh, I. (2001). Management of root-knot nematode Meloidogyne incognita in tomato with organic amendments. Plant Dis. Res. 16, 274-276.

24. Reddy, P.P. (1983). Plant Nematology. Agricole publishing Academy, New Delhi., PP. 10-29.

25. Sakhuja, P.K.; Jain, R.K. (2001). Nematode diseases of vegetable crops and their management. In: Thind, T.S. (ed.), Diseases of Fruits and
Vegetables and their Management. Kalyani Pub., Ludhiana, India.

26. Shehata, S.M. (1972). Evaluation of Some Biological Tests as Parameters for Microbial Activities Related to Soil Fertility. Ph.D. Thesis, Fac. Agric., Cairo Univ., Egypt, p.173.

27. Sheng, X.F.; He, L.Y.; Huang, W.Y. (2002). The conditions of releasing potassium by a silicate dissolving bacterial strain NBT. Agric. Sci. China 1, 662-666.

28. Siddiqui, I.A.; Shaukat, S.S. (2003). Response to carbon starvation in Pseudomonas aeruginosa strain IE-6S+ analysis of general cross protection, production of some nematocidal compounds in vitro and the biological control of Meloidogyne javanica in tomato. World J. Microbiol. Biotechnol. 19, 917-924.

29. Siddiqui, Z.A.; Mahmood, I. (1998). Effect of plant growth promoting bacteria, an AM fungus and soil types on the morphometrics and reproduction of Meloidogyne javanica on tomato. Appl. Soil Ecol. 8, 7784.

30. Snedecor, G.W.; Cochran, W.G. (1989). Statistical Methods. $8^{\text {th }}$ edition, Iowa State Univ. Press, Ames, USA, 158-160.

31. Southey, J.F. (1986). Laboratory methods for work with plant and soil nematodes. Ministry of Agriculture, Fisheries and Food, $6^{\text {th }}$ edition. Ref. Book 402, Her Majesty's Stationery Office, London, p. 202.

32. Sukul, N.C.; Sinhababu, S.P.; Datta, S.C.; Nandi, B., Sukul, A. (2001) Nematotoxic effect of Acacia auriculiformis and Artemisia nilagirica against root-knot nematodes. Allelopathy J. 8, 65-72.

33. Terefe, M.; Tefera, T.; Sakhuja, P.K. (2009). Effect of a formulation of Bacillus firmus on root-knot nematode Meloidogyne incognita infestation and the growth of tomato plants in the greenhouse and nursery. $J$. Inverteb. Pathol. 100, 94-99.

34. Wei, G.; Kloepper, J.W.; Tuzun, S. (1996). Induced systemic resistance to cucumber diseases and increased plant growth by plant growthpromoting rhizobacteria under field conditions. Phytopathol. 86, 221224.

35. Zahra, M.K.; Monib, M.; Abdel-Al, S.H.I.; Heggo, A. (1984). Significance of soil inoculation with silicate bacteria. Zbl. Mikrobiol. 139, 349-357. 